\title{
EL TIEMPO DEL DESCUBRIDOR: LOS NAUFRAGIOS DE CABEZA DE VACA
}

\author{
Emilio Ruiz Granda
}

(Universidad de Oviedo)

En los relatos de los descubridores de sus experiencias y andanzas por el Nuevo Mundo, encontramos el problema de hacer de una narración un instrumento adecuado de intelección y comunicación de la realidad nuevamente conocida. El mismo Cabeza de Vaca acepta la equivalencia entre relato y mentira al decir de los indios:

toda esta gente de indios son grandes amigos de novelas y muy mentirosos, mayormente donde pretenden algún interés (capítulo XXIX).

Los «Naufragios» se presentan como una «relación» (vid. Prohemio) dirigida al rey en la que se intenta, conforme al género (Mignolo, 1980, 1982, Barrera, 1985), dar testimonio personal de incidentes presenciados por el que redacta y organizarlos coherentemente para que cobren sentido. La convención del género lleva, por tanto, a la combinación de la primera persona y el pasado narrativo: el texto se acomoda al tipo de relato epistemológicamente más creíble, según Martínez-Bonati: aquel que refiere, en primera persona, acontecimientos presenciados directamente por quien ha- 
bla. La garante de todo el relato parece ser la memoria personal del narrador que, en sus andanzas:

aunque la esperança que de salir de entre ellos tuve fue siempre muy poca, el cuidado y diligencia siempre fue muy grande de tener particular memoria de todo (Prohemio).

No obstante, la memoria personal, como aval de la facticidad y «certinidad» de lo relatado, no parece criticado suficiente pues, tal como dijo Bertrand Russell: «la memoria no puede dar certeza, por sí sola, de que lo recordado realmente ocurrió, por mucho que podamos reducir lo recordado a su núcleo de experiencia puramente personal» (Russell, 1983: 224). Por añadidura, no existiría una memoria puramente personal: un hombre, para evocar su propio pasado, necesita siempre recurrir a los recuerdos de los otros. Para reconstruir el recuerdo de un acontecimiento es necesario recoger las reproducciones totales o parciales de otros miembros del grupo. Los recuerdos se definen, en todo caso, según referencias colectivas (Halbwachs). En el caso del presente relato, esta necesidad de una sanción colectiva de lo recordado individualmente se evidencia en la continua fluctuación entre el «yo» y el «nosotros» a lo largo de la relación.

Estas reflexiones nos encaminan a la siguiente consideración: para que lo relatado sea aceptado como un discurso verdadero, para que tenga un valor de verdad ( $y$ no degenere en las novelas y mentiras que fascinaban a los indios), es necesario que se ajuste a determinados mecanismos, normas y procedimientos sociales que definen el uso «correcto» de la memoria. La actividad del narrador hade corresponder y reconocerse en una técnica: en este caso, Cabeza de Vaca tiene presentes las reglas que para el recuerdo proporcionaba la mnemotecnia escolástica. Mostraremos esto rápidamente.

Los dos principios básicos de las diversas Ars Mnemonica serían, en primer lugar, la concepción de la realidad en forma de imágenes de tipo emblemático, capaces de impresionar la imaginación y de grabarse en la memoria. En segundo lugar, esas imágenes se alojarán en un sistema de lugares que sirvan de ordenación para aquéllas (Gómez de Liaño). Esto lleva, evidentemente, a que toda actividad mnemónica se asocie a actividades semióticas, en cuanto que el fundamento son las asociaciones en las que $Y$ (el lugar) aparece como significante de X (la imagen) (ECO). Estos dos aspectos orientan el relato del descubridor. En primer lugar por la fijación en lo «extraño» y lo «maravilloso», pues como ya en el Prohemio se reconoce:

aunque en ella se lean algunas cosas muy nuevas y para algunos muy dificiles de creer, pueden sin dubda creerlas... 
El relato circula así por el itinerario de lo real-maravilloso que es causa de "grande admiración». Se fija en aquellos sucesos, costumbres u objetos «extraños» que, de algún modo, impresionan la imaginación:

\begin{abstract}
y vimos una cosa que fue de grande admiración, que los padres y hermanos y mugeres de los que murieron, de verlos en aquel estado, tenían gran pena, y ningún sentimiento hizieron, ni los vimos llorar, ni hablar unos con otros, ni hazer otra ninguna muestra, ni osavan llegar a ellos hasta que nosotros los mandávamos a enterrar (...) antes porque una lloró la llevaron muy lexos de allí y con unos dientes de ratón, agudos, la sajaron desde los hombros hasta casi todas las piernas (cap. XXIX).
\end{abstract}

La memoria se ceba principalmente en la relación de aquellos acontecimientos que por lo hiperbólico o desacostumbrado llegan a impresionar fuertemente la imaginación (como, por ejemplo, los frecuentes casos de canibalismo). Con esto, el narrador no hace sino seguir una de las recomendaciones de la mnemotecnia clásica: en el $A d$ Herennium se proponía, para establecer imágenes capaces de quedar en la memoria el mayor tiempo posible, establecer relaciones lo más chocantes posibles (Ad Herennium, III, XIII): imágenes de belleza o fealdad excepcional, llamativas. Según Yates, el autor de Ad Herennium, expone la idea de que es preciso ayudar a la memoria conectando golpes emocionales con imágenes excepcionales, bellas u horrorosas, con lo cual la Ars Mnemotecnica clásica y medieval nos introduce en una memoria poblada de cosas horribles (Yates, 1975: 21-22).

Habíamos reseñado como segundo rasgo de la técnica de la memoria artificiosa la asociación de las imágenes a diversos lugares. Se recomendaba imaginar un campo o un edificio en el que se iban colocando las diversas imágenes objeto del recuerdo. Este procedimiento domina el relato: cada acontecimiento, cada personaje, cada objeto es recordado en el lugar geográfico que le corresponde:

Aquella bahía de donde partimos ha por nombre bahía de Caballos, y anduvimos siete días por aquellos ancones (Cap. IX).

Los sucesos y las costumbres presenciadas se asocian inmediatamente al entorno en el que ocurrieron:

«En aquella isla que he contado nos quisieron hacer físicos sin examinarnos ni pedirnos los títulos» (Cap. XV).

De este modo el relato discurre a través de un itinerario en el cual se produce una asociación entre los lugares y los sucesos: la memoria personal 
activada en el relato adquiere una sanción social en cuanto que se reconocen en ella una serie de técnicas utilizadas en la época para legitimar el recuerdo del acontecimiento.

No obstante, se podría objetar que el narrador no sigue ninguna técnica, sino que simplemente ocurre que, ante el contacto con una realidad novedosa, se realiza una fijación natural en lo extraño, y que, una vez producido el desastre final de la expedición y librado el relato a su propia suerte, el único referente para ubicar cada suceso pasaba a ser el espacio al haber desaparecido la posibilidad de una medición occidental del tiempo.

Sin embargo, el relato del descubridor no se limita al uso de estos dos recursos que, de modo general, han propuesto las diversas artes de la memoria desde Simonides, sino que encontramos en el relato diversos procedimientos que enraízan en las reglas de la mnemotecnia escolástica y que son las que hacen de este relato un relato moderno en el que se pone en juego y en entredicho el problema de la relación entre tiempo y memoria así como el de la relación entre pasado-presente y futuro. Pasamos a explicitar estas reflexiones.

Aristóteles, en De Anima, plantea que la memoria no es solamente un archivo de datos e imágenes, sino que lo es también de «intentiones», deducidas por la actividad estimativa: la imagen de memoria incluye en sí misma la «intentio». Alberto Magno propuso, a partir de aquí, que una imagen de un lobo contendrá también la «intentio» de que se trata de un animal peligroso; es, por ejemplo, la imagen mental que se forma un cordero de un lobo. En el caso del hombre, la imagen de la Justicia contendrá la «intentio» de adquisición de tal virtud (Yates, 1975: 77). Esto hace de la memoria, no una técnica, sino una parte de las virtudes cardinales, concretamente de la Prudencia.

En la memoria se imprimen imágenes de las virtudes y de los vicios, concebidos como «signos mnemónicos» que deben ayudarnos a ganar el Cielo y evitar el Infierno. Para Boncompagno de Siena, se daba la necesidad primera de recordar Paraíso e Infierno como el ejercicio esencial de la memoria. La memoria, en la escolástica, permite dirigirse de las cosas pasadas a las presentes y las futuras. Aparece entonces la memoria intencional que estabiliza el presente y organiza el devenir en torno a imágenes arquetípicas. En el caso del relato que nos ocupa, es el recuerdo de los suplicios de Cristo lo que permitió al narrador orientar su propia acción en el pasado ${ }^{1}$ :

${ }^{1}$ Esta referencia sitúa la obra dentro del espacio de la representación medieval del mundo, lo que Auerbach dio en llamar la «concepción cristiano-figural»: «Sobre todos los sucesos, por graves que fueran, de curso terrenal, se cernía la dignidad sobresaliente y omnicomprensiva de un solo suceso: el advenimiento de Cristo, y toda tragedia era tan sólo reflejo de una trabazón de sucesos, en la que forzosamente había de desembocar: la trabazón pecado original, nacimiento y pasión de Cristo, juicio final». Auerbach, E., Mimesis. La representación de la realidad en la literatura occidental. Fondo de Cultura Económico, México, 1975, p. 297. 
No tenía, cuando en estos trabajos me vía, otro remedio ni consuelo sino pensar en la passión de nuestro redemptor Jesuchristo y en la sangre que por mí derramó, e considerar cuánto más sería el tormento que de las espinas él padesció, que no aquel que yo entonces sufría (cap. XXII).

El procedimiento, trátese de Paraíso e Infierno o de Jesucristo es idéntico: seleccionar una imagen del pasado que permite soportar el presente a la vez que organizar el devenir. Se puede así controlar el tiempo mediante un modelo para la acción provisto por el archivo de la memoria.

Pero la memoria intencional no sólo trata de fijar normas para la acción en función del paradigma cultural. Hay otro tipo de imagen intencional, más modesta, pero definitoria del relato: se trata de la selección, de entre el conjunto de lo real, de aquellos objetos o situaciones que tienen una trascendencia en el tiempo, que desbordan su presente para proyectarse en el tiempo, haciendo así de la simple sucesión temporal, lugar de aparición y confirmación del sentido del relato. Es, por ejemplo, el recuerdo del «primer muerto»:

Uno de cavallo, que se decía Juan Velázquez, natural de Cuéllar, por no esperar entró en el río, y la corriente, como era rezia, lo derribo del cavallo y se asió de las riendas y ahogó a sí y el cavallo (...) y su muerte nos dio mucha pena porque hasta entonces ninguno nos habia faltado (Cap. V).

Este recuerdo proyecta y construye el tiempo más allá del instante que le corresponde: se convierte en un anticipo del subsecutivo desastre total de la expedición.

Otro objeto explicita esta mecánica del recuerdo que hace de la memoria una virtud: se trata de la manta de martas que arrebatan a un cacique; en principio, parece un detalle sin trascendencia dentro del tráfago de la acción:

los que allí se hallaron prendieron al cacique, más como los suyos estavan tan cerca, soltóseles y dexóles en las manos una manta de martas zebelinas, que son las mejores que yo creo que el mundo se podrían hallar (Cap. IX).

Sin embargo, a través de la memoria narrativa intencional cada detalle es referido porque alberga una «intentio», se proyecta sobre un porvenir anticipado, como la muerte, en el detalle mismo. Capítulos más adelante:

y como los christianos esto supieron, dieron a un indio la manta de martas que del cacique, avíamos tomado, como arriba diximos, porque los passasse donde yo estava, para verme (Cap. XVI). 
El suceso o el objeto, apenas recordado, abre una expectativa de cumplimiento, de modo que el recuerdo se organiza proyectivamente en un instante que supone, en sí, el acabamiento y cumplimiento perfecto de la expectativa que parece abrir. El relato inicia entonces un proceso de connotaciones, en donde cada acontecimiento, siendo por sí mismo un signo se convierte, a su vez, en expresión de un contenido dado deducido del conjunto: El muerto Juan Velázquez, no es sólo eso, es expresión, también, del desastre posterior que caerá sobre la inmensa mayoría de miembros de la infausta expedición; la manta de martas no es sólo un objeto tomado a un cacique, sino un pasaporte que, posteriormente, permitirá que los indios los pasen de una isla a otra. En virtud de esta memoria intencional, el relato propone un proceso semiótico en el que todo objeto, toda situación, denota un suceso en el ahora, en su instante, y a la vez se convierte en emblema de un contenido posterior. Cada objeto, en el relato, supone la apertura hacia un cumplimiento en el futuro. La realidad y cada una de sus porciones y manifestaciones se convierte en signo cargado de connotaciones que vienen a materializar un deseo: hay un único propósito que mueve toda la acción relatada:

mi propósito era pasar a tierra de christianos, y que en este rastro y busca iba (cap. XVII).

Este propósito es el que orienta la memoria intencional que organiza el relato. La narración evidencia, confirma o retrasa la ilusión que mueve al narrador:

En este tiempo, Castillo vio al cuello de un indio una hevilleta de talabarte de espada, y en ella cosido un clavo de herrar; tomóselo y preguntámosle qué cosa era aquella, e dixéronnos que avían venido del cielo (Cap. 2).

El objeto no sólo significa «hevilleta de espada», sino que, una vez reconocido, inicia una intención; supone un nuevo contenido expresado oblicuamente: la presencia y cercanía de cristianos. El relato propone así una memoria intencional en la cual cada objeto, situación o individuo se inscriben en un proceso semiótico en el que pasan a convertirse en expresión de contenidos latentes o diferidos; en rastro o señal de un deseo que recorre y organiza el conjunto. La rememoración hace de la realidad pasada un conjunto de signos cuyo fundamento es la connotación, la expresión de un contenido que es el afán de volver a tierra de cristianos, en este caso.

Esto abre la memoria al tiempo, entendido este último en el sentido de Cassirer de intermediario, en la realización de la acción, entre el instante 
presente y los objetivos marcados, finalmente alcanzados o no: así, el tiempo aparece en esa interrelación entre la memoria (del objetivo, del fin marcado) y la espera (de la consecución ulterior).

Entramos aquí en el segundo aspecto que conecta la actividad memorística narrativa con la mnemotecnia escolástica: para Santo Tomás, la memoria se fundamentaba en la asociación y el orden. Lo importante era asociar las imágenes en un determinado orden; colocar en un orden las cosas que se quieren recordar. Ese orden es el tiempo, dentro del relato, que aparece como el instrumento de organización del recuerdo por medio de las imágenes intencionales. El tiempo se concibe aquí a la manera de Leibniz o Peirce, exclusivamente como forma de orden y de relación entre acontecimientos no simultáneos: el tiempo aparece como forma de organizar la memoria que nos permite decidir qué sucesos han sido afectados por otros anteriores y cuáles no afectaron en nada: «en relación con cualquier estado del sentimiento, todos los demás son de dos clases, los que le afectan (...) y los que no. El presente es afectable por el pasado, pero no por el futuro" (Peirce, 265). Hay, por tanto, a la vez una expectativa abierta y un cumplimiento ya realizado, que precisamente permite establecer las potencialidades inscritas en cada instante (qué sucesos afectarán a otros y es necesario relatar y cuáles no y es posible obviar). La semiotización del presente, que se convierte en significante de un contenido dado en el futuro, otorga al ahora una estabilidad dotada en el después: el presente se fundamenta en el cierre completo del mundo representado, en la sabiduría de que hay una intención ya dada que organiza el recuerdo, dado que este recuerdo es intencional y proyectivo. La fórmula a la que responde la actividad narrativa es la de «entonces no, pero ahora sí». Tal como reconocía A. C. Danto hay una dimensión del acontecimiento que no es abarcable en la misma simultaneidad: se trata de conocer las consecuencias que cada acontecimiento tendrá en el futuro. Esto sólo es posible determinarlo «post eventum», cuando ya se ha cumplido todo definitivamente:

Dexamos muchos arcos turquescos que traíamos y muchos çurrones y flechas y entre ellas las cinco de las esmeraldas, y que no se nos acordó de ellas y ansí las perdimos (Cap. XXXIV).

Entonces no pensó en ellas, pero ahora sí sabe cuándo y dónde las perdió. Sólo en el futuro es posible el conocimiento cumplido del presente, nos dice el relato. El tiempo se define como criterio de organización de la narración situado entre la memoria y la espera, entre la posibilidad y el cumplimiento; es el tránsito entre la situación presente y la consecución del objetivo marcado. El recuerdo permite, en una doble dirección, estabilizar el presente y comprender el futuro. La memoria hace del futuro el lugar en el que se realizarán o no unas posibilidades abiertas en el presente: 
yo pregunté a los christianos y dixe que, si a ellos parescia, rogaría a aquellos indios que nos llevassen a sus casas, y algunos dellos, que avían estado en la Nueva España, respondieron que no se devía hablar en ello, porque si a sus casas nos llevavan, nos sacrificarian a sus ídolos (...) y desde a un hora que aviamos llegado començaron los indios a bailar y hazer grande fiesta (que duró toda la noche) aunque para nosotros no avía placer ni fiesta, ni sueño, esperando cuando nos avian de sacrificar (Cap. XII).

En el relato el recuerdo no es el instrumento de apropiación y acceso al pasado, sino de intelección y semiotización del presente y el devenir. El tiempo aparece en ese intermedio entre lo ya sabido (el recuerdo de los sacrificios) y la espera del cumplimiento de lo rememorado, lo que lleva a la conceptualización del ahora como anticipo del mañana en el que concordarán definitivamente las expectativas del hoy. Es en el final, donde la memoria deja de ser intención para convertirse en archivo acabado de lo que ya está dado en el tiempo. Hasta entonces, hasta que Cabeza de Vaca no satisface su propósito de reencuentro con los españoles, el relato activa una memoria que es apertura y cierre de intenciones y que recurre al tiempo como forma de orden del suceso. Por ello, consideramos que el relato, más bien que conjurar el tiempo por medio de la memoria, lo que confirmaría determinada idea de la memoria como domesticadora y negadora del tiempo (Durand, 1969: 466) vendría a incitar a una caída en éste como único medio de exorcizarlo a través de una memoria que es, a la vez, apertura al futuro y cierre del presente y que enseña a ver en la realidad un mero conjunto de signos.

\section{Bibliografía}

BARRERA, «Los Naufragios de Alvar Núñez Cabeza de Vaca: entre la crónica y la novela», Segundas Jornadas de Andalucía y América (1982), II, Sevilla, 1985.

CABEzA DE VACA, A. Naufragios, Edición de Trinidad Barrera, Alianza Ed., Madrid, 1989.

Durand, G., Les Structures Antropologiques de l'Imaginaire, Ed. Bordas, París, 1969.

ECO, U., «Sobre la dificultad de construir un "Ars Oblivionalis”, Revista de Occidente, $100,1989$.

Gómez de Liaño, I., «Mnemónica y Totemismo», Revista de Occidente, 100, 1989.

MignOLO, W., «Texto y contexto discursivo: el problema de las crónicas indianas», en Texto y Contexto en la Literatura Hispanoamericana, Madrid, 1980, pp. 223-233.

Peirce, Ch. S., El Hombre, Un Signo, Ed. Crítica, Barcelona, 1988.

Russell, B., El Conocimiento Humano, Orbis, Madrid, 1983.

YATES, A., L'Art de la Mémoire, Gallimard, París, 1975. 